\title{
Evaluation of a low dose, after a standard therapeutic dose, of agalsidase beta during enzyme replacement therapy in patients with Fabry disease
}

\author{
Jean-Claude Lubanda, $M D, P h D^{I}$, Ene Anijalg, $M D^{2}$, Vladimir Bzdúch, $M D, P h D^{3}$, \\ Beth L. Thurberg, MD, PhD ${ }^{4}$, Bernard Bénichou, MD, PhD ${ }^{5}$, and Anna Tylki-Szymanska, MD, PhD
}

\begin{abstract}
Purpose: Fabry disease, a genetic deficiency of $\alpha$-galactosidase A, is characterized by pathogenic cellular accumulation of globotriaosylceramide. During clinical trials, recombinant human $\alpha$-galactosidase A (agalsidase beta; Fabrazyme ${ }^{\circledR}$, Genzyme Corporation, Cambridge, MA), infused intravenously at $1.0 \mathrm{mg} / \mathrm{kg}$ every 2 weeks for 6 months, cleared or reduced globotriaosylceramide in renal, cardiac, and dermal microvascular endothelia and other cells, with results sustained for up to 5 years in most patients evaluated. This study explored whether a lower dose could maintain globotriaosylceramide clearance achieved with 1.0 $\mathrm{mg} / \mathrm{kg}$. Methods: Cellular globotriaosylceramide levels were assessed histologically in kidney and skin biopsies from 21 adult Fabry males treated for 6 months at $1.0 \mathrm{mg} / \mathrm{kg} / 2$ weeks followed by 18 months at 0.3 $\mathrm{mg} / \mathrm{kg} / 2$ weeks. Results: In kidney interstitial capillary endothelium, the primary endpoint, globotriaosylceramide clearance was achieved in $100 \%$ of patients with $1.0 \mathrm{mg} / \mathrm{kg}$ and maintained in $90 \%$ with 0.3 $\mathrm{mg} / \mathrm{kg}$. In seven other renal cell types and superficial dermal capillary endothelium, globotriaosylceramide reduction or clearance was maintained with $0.3 \mathrm{mg} / \mathrm{kg}$ in $\sim 70 \%$ of patients. Conclusions: A lower dose of agalsidase beta may be sufficient in some, but not all, patients with Fabry disease to maintain the cellular globotriaosylceramide clearance achieved with $1.0 \mathrm{mg} / \mathrm{kg} / 2$ weeks. Long-term clinical effects of transitioning to the lower dose have not been evaluated. Genet Med 2009:11(4):256-264.
\end{abstract}

Key Words: Fabry disease, agalsidase beta, $\alpha$-galactosidase A, globotriaosylceramide, enzyme replacement therapy

Eabry disease (OMIM 301500) is a lysosomal storage disorder - caused by mutations of the X-linked gene that encodes the exoglycohydrolase, $\alpha$-galactosidase A ( $\alpha \mathrm{GAL}$; EC 3.2.1.22). Deficient activity of the enzyme impairs normal metabolism of

\footnotetext{
From the ${ }^{1}$ Clinical Department of Cardiology and Angiology, Charles University in Prague, First Faculty of Medicine, Prague, Czech Republic; ${ }^{2}$ Department of Internal Medicine, Tartu University Clinics, Tartu, Estonia; ${ }^{3}$ Department of Pediatrics, Comenius University Children's Hospital, Bratislava, Slovak Republic; ${ }^{4}$ Genzyme Corporation, Cambridge, Massachusetts; ${ }^{5}$ Genzyme Europe, Saint-Germain-en-Laye, France; and the ${ }^{6}$ Clinic of Metabolic Diseases, Endocrinology and Diabetology, The Children's Memorial Health Institute, Warsaw, Poland.
}

Jean-Claude Lubanda, MD, PhD, Clinical Department of Cardiology and Angiology, Charles University in Prague, First Faculty of Medicine, Prague, Czech Republic. E-mail: lubanda@mail.cz.

Disclosure: Jean-Claude Lubanda, Paid by Genzyme as Investigator for AGAL 017 Study, Received honoraria from Genzyme for lectures; Ene Anijalg, Paid by Genzyme as Principal Investigator for AGAL 017 Study; Vladimir Bzduch, Paid by Genzyme as Principal Investigator for AGAL 017 Study; Bernard Bénichou, Employed by Genzyme; Beth M. Thurberg, Employed by Genzyme; Anna Tylki-Szymanska, Received honoraria from Genzyme for lectures, Paid by Genzyme as Principal Investigator for AGAL 017 Study.

Submitted for publication July 14, 2008.

Accepted for publication December 8, 2008

DOI: $10.1097 /$ GIM.0b013e3181981d82 globotriaosylceramide (GL-3) and related glycosphingolipids, resulting in the pathogenic accumulation of incompletely catabolized substrates within most cells and tissues. ${ }^{1}$ In addition, circulating factors, such as the recently identified deacylated metabolite of GL-3, may be biologically active and contribute to disease pathogenesis. ${ }^{2,3}$ Multiple organ systems are adversely affected in Fabry disease, with life-threatening consequences stemming from progressive renal, cardiac, and cerebrovascular involvement. Enzyme replacement therapy (ERT) with agalsidase beta (Fabrazyme $\AA$, Genzyme Corporation, Cambridge, MA), a form of recombinant human $\alpha \mathrm{GAL}$, reduces or clears accumulated substrates from certain renal, cardiac, and dermal cell populations and from plasma. ${ }^{4-7}$ ERT with agalsidase beta therapy has also been reported to stabilize or slow renal and cardiac progression of the disease, especially when initiated before irreversible end-organ damage has occurred.6,8-11

The recommended therapeutic dosage regimen for agalsidase beta specifies intravenous infusions at $1.0 \mathrm{mg} / \mathrm{kg}$ body weight every 2 weeks. For the majority of patients who participated in clinical trials, $\sim 6$ months of treatment with this dosage regimen resulted in complete clearance of GL-3 deposits from the microvascular endothelia of the kidney, heart, and skin, and from other renal cell types. $5,7,12,13$ After up to an additional 54 months of treatment, clearance was sustained in most patients evaluated. ${ }^{6}$ Because ERT must continue throughout the lifetime of patients with this genetic disease, it is of interest to know whether a dose lower than $1.0 \mathrm{mg} / \mathrm{kg}$ would be sufficient to maintain clearance of GL-3. Therefore, an exploratory study was conducted to evaluate a treatment regimen in which patients were treated for 6 months with agalsidase beta at 1.0 $\mathrm{mg} / \mathrm{kg} / 2$ weeks to clear accumulated substrate from cells of the kidney and skin, and then treated for 18 months with 0.3 $\mathrm{mg} / \mathrm{kg} / 2$ weeks to assess whether the lower dose could maintain cells in a cleared state. GL-3 levels in plasma and urine were also assessed, and safety was monitored throughout the study.

\section{METHODS}

\section{Patient population}

Inclusion criteria required that participants were male, were at least 16 years of age, exhibited clinical manifestations consistent with Fabry disease, and had documented levels of $\alpha \mathrm{GAL}$ activity $<1.5 \mathrm{nmol} /$ hour $/ \mathrm{mL}$ in plasma or $<4 \mathrm{nmol} /$ hour $/ \mathrm{mg}$ in leukocytes. Exclusion criteria included prior treatment with ERT, serum creatinine $\geq 2.2 \mathrm{mg} / \mathrm{dL}$, kidney transplantation, dialysis, clinically significant organic disease or an unstable condition that in the investigator's opinion precluded participation. The ethics committee at each center approved the protocol. Written informed consent was obtained from patients before initiation of study procedures. A total of 21 patients were screened; all 21 enrolled and completed the study between June 2003 and April 2006. 


\section{Study design}

This trial was an open-label, single-arm study conducted at four centers in four countries. The study duration was 96 weeks. After baseline assessments, patients received 12 infusions of agalsidase beta at $1.0 \mathrm{mg} / \mathrm{kg} / 2$ weeks for 6 months (Weeks 0-23), followed by up to 37 infusions at $0.3 \mathrm{mg} / \mathrm{kg} / 2$ weeks for 18 months (Weeks 24-96). Infusions of $1.0 \mathrm{mg} / \mathrm{kg}$ were administered at an initial rate of $0.25 \mathrm{mg} /$ minute. For the first 8 infusions, the infusion duration could not be $<4$ hours; for the remaining 4 infusions of the 1.0 $\mathrm{mg} / \mathrm{kg}$ dose, the infusion rate could be gradually increased at the investigator's discretion, but 90 minutes was the minimum infusion duration permitted. The first infusion of $0.3 \mathrm{mg} / \mathrm{kg}$ was administered at the same protein load ( $\mathrm{mg} /$ minute) as the last infusion of $1.0 \mathrm{mg} / \mathrm{kg}$. The infusion rate could be gradually increased at subsequent infusions, but 30 minutes was the minimum infusion duration permitted. If needed to manage adverse reactions during infusions, acetaminophen (paracetamol) or ibuprofen could be administered before infusions. An independent board was assigned to monitor safety and efficacy data and to recommend trial interruption if warranted. If a patient relapsed during the $0.3-\mathrm{mg} / \mathrm{kg}$ period as evidenced by a combination of significant clinical deterioration and significant GL-3 re-accumulation in plasma or skin (which were regularly monitored throughout the low-dose period), the dose was to be increased to $1.0 \mathrm{mg} / \mathrm{kg}$. No patient met both criteria for relapse. Patient 14 was returned to $1.0 \mathrm{mg} / \mathrm{kg}$ at Week 76 on the basis of deterioration of renal function only (see below).

\section{Efficacy assessments}

The primary efficacy endpoint was the percentage of patients who maintained clearance of GL-3 from kidney interstitial capillary endothelial cells during the $0.3-\mathrm{mg} / \mathrm{kg}$ period compared to the percentage who initially achieved clearance during the $1.0-\mathrm{mg} / \mathrm{kg}$ period. "Clearance" was defined as a score of zero on histological assessments of biopsy tissue during treatment. For secondary efficacy endpoints, clearance of GL-3 was monitored in seven other renal cell populations (see Table 1) and in dermal capillary endothelial cells, and GL-3 concentrations in plasma and urine were assessed.

\section{Histological assessments}

Kidney biopsies were performed at baseline and Weeks 24 and 96. Skin biopsies were performed at baseline and Weeks 24, 48, 72 , and 96 . Biopsy tissue was processed for light microscopy. ${ }^{12,13}$ Slides were masked for patient identification and sampling time, and were scored independently by three pathologists with expertise in the tissue examined. For mesangial cells and interstitial cells of the kidney, lipid granules were scored as none (0), minimal (1), or numerous (2); for all other kidney cells and for the superficial capillary endothelium of the dermis, GL-3 accumulation was rated as clear or trace (0), mild (1), moderate (2), severe (3). ${ }^{5,12,13} \mathrm{~A}$ majority score was calculated for each tissue section from the three pathologists' scores. If there was not a majority score and if a majority score could not be derived by an adjudication process involving the three pathologists, the median score was used. For statistical analyses of clearance, scores were categorized as either "zero" (cleared) or "nonzero" (not cleared). Additionally, for kidney, a composite GL-3 score was calculated by summing a patient's majority scores for the eight renal cell types. A composite kidney GL-3 score was computed only when all eight cell types were assessable in a given biopsy specimen. Possible composite kidney GL-3 scores ranged from 0 (all clear or trace) to 22 (all severe or numerous).
Table 1 Percentage of patients with zero scores for GL-3 accumulation in kidney cells

\begin{tabular}{|c|c|c|c|}
\hline \multirow[b]{2}{*}{ Cell population } & \multicolumn{3}{|c|}{$\begin{array}{l}\% \text { of Patients with zero scores } \\
\text { (no. patients analyzed) }\end{array}$} \\
\hline & $\begin{array}{c}\text { Baseline } \\
\text { pretreatment }\end{array}$ & $\begin{array}{c}\mathrm{Wk} 24 \\
1.0-\mathrm{mg} / \mathrm{kg} / 2 \text { wk }\end{array}$ & $\begin{array}{c}\text { Wk } 96 \\
0.3-\mathrm{mg} / \mathrm{kg} / 2 \text { wk }\end{array}$ \\
\hline \multirow{3}{*}{$\begin{array}{l}\text { Interstitial } \\
\text { capillary } \\
\text { endothelial } \\
\text { cells }\end{array}$} & 14 & 100 & 90 \\
\hline & (21) & (21) & $(20)^{a}$ \\
\hline & & $P<0.001^{b}$ & $P=0.25^{c}$ \\
\hline \multirow{3}{*}{$\begin{array}{l}\text { Glomerular } \\
\text { endothelial } \\
\text { cells }\end{array}$} & 26 & 100 & 100 \\
\hline & (19) & (19) & (17) \\
\hline & & $P<0.001^{b}$ & $\mathrm{NC}^{c}$ \\
\hline \multirow[t]{3}{*}{ Mesangial cells } & 16 & 100 & 100 \\
\hline & (19) & (19) & (17) \\
\hline & & $P<0.001^{b}$ & $\mathrm{NC}^{c}$ \\
\hline \multirow{3}{*}{$\begin{array}{l}\text { Noncapillary } \\
\text { endothelial } \\
\text { cells }\end{array}$} & 14 & 100 & 100 \\
\hline & (21) & (20) & (19) \\
\hline & & $P<0.001^{b}$ & $\mathrm{NC}^{c}$ \\
\hline \multirow[t]{3}{*}{ Interstitial cells } & 14 & 86 & 85 \\
\hline & (21) & (21) & (20) \\
\hline & & $P<0.001^{b}$ & $P=1.00^{c}$ \\
\hline \multirow{3}{*}{$\begin{array}{l}\text { Distal convoluted } \\
\text { tubule and } \\
\text { collecting duct } \\
\text { cells }\end{array}$} & 10 & 52 & 30 \\
\hline & (21) & (21) & (20) \\
\hline & & $P=0.004^{b}$ & $P=0.55^{c}$ \\
\hline \multirow{3}{*}{$\begin{array}{l}\text { Noncapillary } \\
\text { smooth muscle } \\
\text { cells }\end{array}$} & 5 & 30 & 53 \\
\hline & (21) & (20) & (19) \\
\hline & & $P=0.06^{b}$ & $P=0.29^{c}$ \\
\hline \multirow[t]{3}{*}{ Podocytes } & 0 & 0 & 0 \\
\hline & (19) & (19) & (17) \\
\hline & & $\mathrm{NC}^{b}$ & $\mathrm{NC}^{c}$ \\
\hline
\end{tabular}

$\overline{{ }^{a}}$ These cells were evaluated as the primary efficacy endpoint. Week-96 biopsy data were not available for Patient 14 .

${ }^{b}$ Week 24 compared to Baseline; NC, no change from baseline.

${ }^{\mathrm{c}}$ Week 96 compared to Week 24; NC, no change from Week 24.

\section{Biochemical assessments}

Plasma GL-3 levels were measured every 6 weeks using mass spectrometry. ${ }^{14}$ Urine GL-3 levels were measured every 12 weeks in first morning void samples. GL-3 concentrations were determined in urine sediment by tandem mass spectrometry. ${ }^{15}$

\section{Clinical assessments}

At baseline and every 12 weeks, a 12-lead electrocardiogram and a physical examination were performed, and samples obtained for hematology, blood chemistry, and urinalysis were analyzed by a central laboratory. Serum creatinine levels, assayed by the alkaline picrate method, were used to calculate estimated glomerular filtration rate (eGFR) by the MDRD equation. ${ }^{16}$ Proteinuria (g protein/g creatinine) was determined from 24-hour urine collections. 


\section{Safety assessments}

The results of clinical assessments were reviewed regularly, and concomitant medications and adverse events (AEs) were monitored throughout the study. AEs were coded using the Medical Dictionary of Regulatory Activities (MedDRA; Version 8.1). Treatment-emergent AEs, defined as those that began during or after the first infusion, are reported here. At baseline and every 6 weeks, serum titers of IgG antibodies to agalsidase beta were determined. ${ }^{11,17}$ Patients were considered seropositive when a positive signal on enzyme-linked immunosorbent assay was confirmed by radioimmunoprecipitation. Antibody titers were reported as the inverse of the highest serum dilution that yielded a positive enzyme-linked immunosorbent assay signal.

\section{Statistical methods}

The sample size was calculated to detect a difference in the primary endpoint between baseline and Week 24 (not between Weeks 24 and 96), based on the results of the Phase 3 trial of agalsidase beta. ${ }^{4}$ A sample size of 20 was estimated by the exact sign test of equality of paired proportions by assuming a twotailed test with $\alpha<0.05$ and $\beta=0.80$ and setting the proportion of patients with zero scores for GL-3 accumulation in kidney interstitial capillary endothelial cells to 0.17 at baseline and 0.69 at Week 24, and 0.69 in discordant cells. Statistical analyses were performed on the intent-to-treat population. For kidney and skin cells, an exact binomial matched pairs procedure was used to compare the percentages of patients with a zero score at baseline to those at Week 24, and at Week 24 to those at subsequent time points. For composite kidney GL-3 scores, a $t$-test was used to compare the change from baseline to Week 24 and from Week 24 to Week 96. For GL-3 levels in plasma and urine, a $t$-test was used to compare baseline values and average values during the $1.0-\mathrm{mg} / \mathrm{kg}$ period, and average values during the $1.0-$ and $0.3-\mathrm{mg} / \mathrm{kg}$ periods. For the post hoc analysis of anti- $\alpha$ GAL IgG antibodies, patients were subgrouped by peak titer values, and, for each subgroup, a paired $t$-test was used to compare the baseline value for urinary GL-3 to the average value during the $1.0 \mathrm{mg} / \mathrm{kg}$ and the average value during the $0.3-\mathrm{mg} / \mathrm{kg}$ period. A $P$-value less than or equal to 0.05 was considered statistically significant.

\section{RESULTS}

\section{Study population}

The 21 study participants were Caucasian males with a baseline age ranging from 19.9 to 55.3 years (Table 2). The age at onset of Fabry disease symptoms ranged from 6 to 14 years (median, 8 years) and, at disease diagnosis, from 7 to 49 years (median, 28 years). All patients had at least one family member who was diagnosed with Fabry disease. Table 2 lists the $\alpha \mathrm{GAL}$ mutations for the patients, which included one large genomic deletion that removes exon 2 from the transcript, four deletions in the coding region that predict a translational frameshift and premature stop codon, and 2 nonsense and 6 missense mutations. Five of the mutations occurred in more than one patient; identical mutations were clustered at the same study center, but family relationships between patients were not documented. Signs and symptoms of Fabry disease reported for $>50 \%$ of the patients were: angiokeratoma (81\%), acroparaesthesia (71\%), left ventricular hypertrophy $(57 \%)$, proteinuria $(57 \%)$, and pain $(57 \%)$. A history of stroke was reported for two patients, both with the p.Leu19Pro substitution.
All 21 patients received the 12 planned infusions during the $1.0-\mathrm{mg} / \mathrm{kg}$ period. During the $0.3-\mathrm{mg} / \mathrm{kg}$ period, 19 patients received the 37 planned infusions; Patient 14 received 26 infusions at $0.3 \mathrm{mg} / \mathrm{kg}$ before reversion to $1.0 \mathrm{mg} / \mathrm{kg}$ at Week 76 ; Patient 12 received only 32 infusions at $0.3 \mathrm{mg} / \mathrm{kg}$ because he refused infusions after Week 84, although he agreed to complete the final study visit 3 weeks earlier than scheduled. Protocol deviations occurred for two patients who received up to 1.4 $\mathrm{mg} / \mathrm{kg}$ for some infusions of $1.0 \mathrm{mg} / \mathrm{kg}$ and up to $0.6 \mathrm{mg} / \mathrm{kg}$ for the first infusion of $0.3 \mathrm{mg} / \mathrm{kg}$. In accordance with infusion guidelines (see Methods), the mean duration of infusions decreased from 4.5 hours to 4.0 hours during the 6-month, 1.0$\mathrm{mg} / \mathrm{kg}$ period and from 2.0 hours to 1.4 hours during the 18-month, $0.3-\mathrm{mg} / \mathrm{kg}$ period.

\section{Histological and biochemical assessments of GL-3 levels}

For the 8 kidney cell populations evaluated, Table 1 displays the percentage of patients with zero scores (indicating clearance or only trace GL-3 deposits) at each time point. For the interstitial capillary endothelial cells assessed as the primary efficacy endpoint, the percentage of patients with zero scores increased from $14 \%$ at baseline to $100 \%$ during the $1.0-\mathrm{mg} / \mathrm{kg}$ period $(P<0.001$, baseline vs. Week 24$)$ and decreased to $90 \%$ during the $0.3-\mathrm{mg} / \mathrm{kg}$ period $(P=0.25$, Week 24 vs. Week 96). A statistically significant increase in the percentage of patients with zero scores was also seen between baseline and Week 24 for all other renal cell types except noncapillary smooth muscle cells and podocytes. From Week 24 to 96, no statistically significant changes were observed for any renal cell type. Although zero scores were not assigned to podocytes for any patient at any time point, scores for podocytes improved relative to baseline for 3 of 19 patients at Week 24 and 9 of 17 patients at Week 96. Table 3 demonstrates that the mean composite GL-3 score for all kidney cell types decreased (improved) significantly $(P<0.001)$ from baseline to Week 24 , but did not change $(P=0.06)$ from Week 24 to 96 . For Patients 4,8 , and 21 , Week-96 composite kidney GL-3 scores were higher than Week-24 scores. For Patient 5, the Week-96 composite kidney GL-3 score decreased despite an increased score for one cell type; and, for Patients 9 and 12, increased scores were noted in up to three cell types but data were not available for all cell types so a composite kidney GL-3 score could not be calculated.

For the superficial dermal capillary endothelial cells (Fig. 1), the percentage of patients with zero scores increased significantly $(P<0.001)$ from $24 \%$ at baseline to $95 \%$ at Week 24 of the $1.0-\mathrm{mg} / \mathrm{kg}$ period, followed by decreases to $70-80 \%$ at Week $48(P=0.06)$, Week $72(P=0.25)$, and Week $96(P=$ $0.25)$ of the $0.3-\mathrm{mg} / \mathrm{kg}$ period. A total of seven patients had GL-3 scores at one or more of the later time points that were higher than their Week-24 score. New angiokeratomas were spontaneously reported for Patients 8 and 9; Patient 9 exhibited nonzero scores in the dermal capillary endothelium during the $0.3-\mathrm{mg} / \mathrm{kg}$ period, but Patient 8 did not.

Table 3 shows that the mean level of plasma GL-3, which was above the normal range $(\leq 7.0 \mu \mathrm{g} / \mathrm{mL})$ at baseline, decreased $(P<0.001)$ to normal levels during the $1.0-\mathrm{mg} / \mathrm{kg}$ period and subsequently did not show a statistically significant change $(P=0.66)$ during the $0.3-\mathrm{mg} / \mathrm{kg}$ period. However, although only one patient had elevated plasma GL-3 at the end of standard-dose treatment, 10 patients exhibited elevated plasma GL-3 on at least one occasion during low-dose treatment. For urine GL-3, the mean level decreased significantly $(P<0.001)$ from baseline to the $1.0-\mathrm{mg} / \mathrm{kg}$ period but a 
Table 2 Patient genotypes and baseline data

\begin{tabular}{|c|c|c|c|c|c|}
\hline Patient & $\begin{array}{l}\text { Mutation }^{a} \\
\text { Deletions }\end{array}$ & $\begin{array}{l}\text { Predicted mutant } \\
\operatorname{protein}^{b}\end{array}$ & $\begin{array}{l}\text { Age } \\
\text { (years) }\end{array}$ & $\begin{array}{c}\text { eGFR } \\
\left(\mathrm{mL} / \mathrm{min} / 1.73 \mathrm{~m}^{2}\right)\end{array}$ & $\begin{array}{c}\text { Proteinuria } \\
\text { (g protein } / \mathrm{g} \text { creatinine) }\end{array}$ \\
\hline 1 & g.3396_6012del & p.Ser65FSX6 $6^{c, d}$ & 35.7 & 86 & 0.1 \\
\hline 2 & c.674_732del & p.His $225 \mathrm{FSX} 4^{c, d}$ & 27.8 & 107 & $\mathrm{n} / \mathrm{a}$ \\
\hline 3 & c.674_732del & p.His $225 \mathrm{FSX} 4^{c, d}$ & 37.6 & 94 & 0.1 \\
\hline 4 & c.674_732del & p.His $225 \mathrm{FSX} 4^{c, d}$ & 38.0 & 96 & 0.2 \\
\hline 5 & c.674_732del & p.His $225 \mathrm{FSX} 4^{c, d}$ & 47.0 & 75 & 0.2 \\
\hline 6 & c.717_718del & p.Ile239Ile_FSX29 $9^{c, d}$ & 38.3 & 97 & 0.6 \\
\hline 7 & c. $777 \mathrm{del}$ & p.Pro259Pro_FSX9 $9^{c, d}$ & 19.2 & 134 & 0.2 \\
\hline \multirow[t]{2}{*}{8} & c.803_806del & p.Leu268FSX ${ }^{c, d}$ & 51.4 & 82 & 0.3 \\
\hline & Nonsense & & & & \\
\hline 9 & c. $369 \mathrm{~T}>\mathrm{G}$ & pTyr123X $X^{d}$ & 20.5 & 119 & 0.2 \\
\hline \multirow[t]{2}{*}{10} & c. $901 \mathrm{C}>\mathrm{T}$ & p.Arg $301 X^{d}$ & 55.3 & 82 & 0.5 \\
\hline & Missense & & & & \\
\hline 11 & c. $56 \mathrm{~T}>\mathrm{C}$ & p.Leu19Pro & 28.8 & 95 & 0.1 \\
\hline 12 & c. $.56 \mathrm{~T}>\mathrm{C}$ & p.Leu19Pro & 35.9 & 85 & 1.4 \\
\hline 13 & c. $101 \mathrm{~A}>\mathrm{G}$ & p.Asn34Ser & 19.9 & 104 & 0.3 \\
\hline 14 & c. $101 \mathrm{~A}>\mathrm{G}$ & p.Asn34Ser & 34.8 & 75 & 3.4 \\
\hline 15 & c. $128 \mathrm{G}>\mathrm{A}$ & p.Gly43Asp & 24.1 & 90 & 5.0 \\
\hline 16 & c. $950 \mathrm{~T}>\mathrm{C}$ & p.Ile317Thr & 22.5 & 103 & 0.2 \\
\hline 17 & c. $950 \mathrm{~T}>\mathrm{C}$ & p.Ile317Thr & 30.3 & 61 & 1.4 \\
\hline 18 & c. $950 \mathrm{~T}>\mathrm{C}$ & p.Ile317Thr & 37.2 & 55 & 2.7 \\
\hline 19 & c. $1022 \mathrm{~A}>\mathrm{G}$ & p.Glu341Gly & 29.6 & 108 & 0.3 \\
\hline 20 & c. $1022 \mathrm{~A}>\mathrm{G}$ & p.Glu341Gly & 37.1 & 132 & 0.9 \\
\hline 21 & c. $1025 \mathrm{G}>\mathrm{A}$ & p.Arg342Gln & 43.4 & 63 & 1.3 \\
\hline Mean & & & 34.0 & 93 & 0.9 \\
\hline Standard deviation & & & 10.0 & 21 & 1.3 \\
\hline Median & & & 35.7 & 94 & 0.3 \\
\hline Minimum, maximum & & & $19.9,55.3$ & 55,134 & $0.1,5.0$ \\
\hline$N$ & & & 21 & 21 & 20 \\
\hline
\end{tabular}

statistically significant $(P=0.001)$ increase was seen between the 1.0 - and the $0.3-\mathrm{mg} / \mathrm{kg}$ periods (Table 3). A post hoc analysis of these data is reported below.

\section{Renal function assessments}

Median values for eGFR were 92.5, 93.1, and $92.8 \mathrm{~mL} /$ minute $/ 1.73 \mathrm{~m}^{2}$ at baseline, Week 24 and 96 , respectively, with baseline eGFR values below $90 \mathrm{~mL} /$ minute $/ 1.73 \mathrm{~m}^{2}$ for 10 of 21 patients (Table 2). Median proteinuria was $0.3,0.4$, and $0.3 \mathrm{~g} / \mathrm{g}$ at baseline, Week 24 and 96 , respectively; levels in the nephrotic range $(>3.0 \mathrm{~g} / \mathrm{g})$ were seen in 2 of 21 patients at baseline (Table 2). No statistically significant changes were found for the study cohort during either dose period, but clinically significant renal developments were observed for four patients: For the two patients with baseline proteinuria $>3.0 \mathrm{~g} / \mathrm{g}$, Patient 14 progressed from $75 \mathrm{~mL} /$ minute $/ 1.73 \mathrm{~m}^{2}$ to end stage renal disease and began dialysis late in the study, and Patient 15 experienced a decline in eGFR from 90 to $45 \mathrm{~mL} /$ minute $/ 1.73 \mathrm{~m}^{2}$ from baseline to Week 96. For Patients 8 and 19, proteinuria increased above $3.0 \mathrm{~g} / \mathrm{g}$ during the study; eGFR declined from 82 to 65 $\mathrm{mL} /$ minute $/ 1.73 \mathrm{~m}^{2}$ for Patient 8 but remained normal for 
Table 3 By-patient summary of GL-3 levels in cells, urine, and plasma before and during standard- low-dose treatment

\begin{tabular}{|c|c|c|c|c|c|c|c|c|c|c|c|c|c|c|c|}
\hline \multirow[b]{3}{*}{ Patient no. } & \multirow{3}{*}{$\begin{array}{l}\text { Peak IgG } \\
\text { antibody } \\
\text { titer }\end{array}$} & \multicolumn{3}{|c|}{$\begin{array}{l}\text { Composite kidney } \\
\text { GL-3 score }\end{array}$} & \multicolumn{5}{|c|}{$\begin{array}{l}\text { Dermal Capillary endothelium } \\
\text { GL-3 scores }\end{array}$} & \multicolumn{3}{|c|}{$\begin{array}{c}\text { Urine } \\
\text { GL-3 }(\mu \mathrm{g} / \mathrm{mg} \text { creatine })\end{array}$} & \multicolumn{3}{|c|}{$\begin{array}{c}\text { Plasma } \\
\text { GL-3 }(\mu \mathrm{g} / \mathrm{mL})\end{array}$} \\
\hline & & \multirow{2}{*}{\multicolumn{2}{|c|}{$\begin{array}{c}1 \\
\begin{array}{c}1 \\
(\mathrm{mg} / \mathrm{kg})\end{array} \\
\mathrm{BL} \quad \text { Wk } 24\end{array}$}} & \multirow{2}{*}{$\begin{array}{c}0.3 \\
(\mathrm{mg} / \mathrm{kg}) \\
\text { Wk } 96\end{array}$} & \multirow[b]{2}{*}{$\mathrm{BL}$} & \multirow{2}{*}{$\begin{array}{c}1 \\
(\mathrm{mg} / \mathrm{kg}) \\
\text { Wk } 24\end{array}$} & \multicolumn{3}{|c|}{$0.3(\mathrm{mg} / \mathrm{kg})$} & \multirow[b]{2}{*}{$\mathrm{BL}$} & \multirow{2}{*}{$\begin{array}{l}1 \mathrm{mg} / \mathrm{kg} \\
\text { Wk 1-24 } \\
\text { Average }\end{array}$} & \multirow{2}{*}{$\begin{array}{c}0.3 \mathrm{mg} / \mathrm{kg} \\
\text { Wk } 25-96 \\
\text { Average }\end{array}$} & \multirow[b]{2}{*}{$\mathrm{BL}$} & \multirow{2}{*}{$\begin{array}{c}1 \mathrm{mg} / \mathrm{kg} \\
\mathrm{Wk} \mathrm{1-24} \\
\text { Average }\end{array}$} & \multirow{2}{*}{$\begin{array}{c}0.3 \mathrm{mg} / \mathrm{kg} \\
\text { Wk } 25-96 \\
\text { Average }\end{array}$} \\
\hline & & & & & & & Wk 48 & Wk 72 & Wk 96 & & & & & & \\
\hline 1 & 3200 & 11 & 4 & 2 & 2 & 0 & 0 & 0 & 0 & 224 & 81 & 149 & 14.4 & 6.9 & 6.5 \\
\hline 2 & 1600 & 18 & 5 & 3 & 2 & 0 & 0 & 0 & 0 & 116 & 67 & 42 & 12.9 & 7.0 & 6.2 \\
\hline 3 & 25,600 & 19 & 5 & 3 & 0 & 0 & 1 & 2 & 2 & 107 & 143 & 222 & 10.6 & 5.8 & 5.6 \\
\hline 4 & 6400 & 10 & 3 & 6 & 2 & $1^{a}$ & 2 & 1 & 1 & 109 & 163 & 299 & 13.4 & 7.4 & 6.6 \\
\hline 5 & 3200 & 11 & 5 & 3 & 3 & 0 & 1 & 0 & 0 & 125 & 132 & 154 & 9.2 & 4.6 & 4.0 \\
\hline 6 & 25,600 & 18 & 6 & 3 & 2 & 0 & 1 & 1 & 2 & 257 & 149 & 289 & 13.3 & 5.4 & 6.2 \\
\hline 7 & 3200 & $\mathrm{n} / \mathrm{a}$ & 8 & 5 & 2 & 0 & 0 & 0 & 0 & 478 & 49 & 87 & 11.5 & 5.3 & 5.0 \\
\hline 8 & 6400 & 17 & 3 & 7 & 2 & 0 & 0 & 0 & 0 & 4 & 23 & 34 & 13.1 & 7.1 & 6.6 \\
\hline 9 & 3200 & 19 & 4 & $\mathrm{n} / \mathrm{a}$ & 2 & 0 & 1 & 0 & 1 & 298 & 44 & 111 & 11.5 & 4.4 & 5.1 \\
\hline 10 & 400 & 3 & 3 & 3 & 0 & 0 & 0 & 0 & 0 & 87 & 21 & 26 & 6.0 & 4.8 & 4.4 \\
\hline 11 & 800 & 20 & 7 & 4 & 3 & 0 & 0 & 0 & 0 & 245 & 32 & 60 & 13.7 & 5.4 & 5.0 \\
\hline 12 & 3200 & 16 & 5 & $\mathrm{n} / \mathrm{a}$ & 2 & 0 & 0 & 0 & 0 & 410 & 226 & $350^{a}$ & 14.1 & 6.3 & $6.2^{a}$ \\
\hline 13 & 1600 & 16 & $\mathrm{n} / \mathrm{a}$ & $\mathrm{n} / \mathrm{a}$ & 3 & 0 & 0 & 0 & 0 & 159 & 17 & 8 & 10.9 & 4.8 & 4.9 \\
\hline 14 & 12,800 & 19 & $\mathrm{n} / \mathrm{a}$ & $\mathrm{n} / \mathrm{a}$ & 1 & 0 & 0 & 0 & $\mathrm{n} / \mathrm{a}$ & 636 & 187 & $194^{b}$ & 16.1 & 7.4 & $5.8^{b}$ \\
\hline 15 & 6400 & $\mathrm{n} / \mathrm{a}$ & 7 & 4 & 3 & 0 & 0 & 1 & 0 & 21 & 13 & 37 & 21.4 & 6.9 & 9.0 \\
\hline 16 & 0 & 5 & 2 & 2 & 0 & 0 & 0 & 0 & 0 & 337 & 8 & 11 & 6.5 & 3.5 & 4.0 \\
\hline 17 & 0 & 7 & 4 & 2 & 0 & 0 & 0 & 0 & 0 & 241 & 8 & 40 & 10.8 & 6.2 & 6.1 \\
\hline 18 & 800 & 6 & 4 & 2 & 0 & 0 & 0 & 0 & 0 & 243 & 53 & 68 & 9.4 & 5.4 & 6.1 \\
\hline 19 & 0 & 18 & 6 & 2 & 2 & 0 & 0 & 0 & 0 & 247 & 5 & 14 & 9.4 & 6.5 & 5.1 \\
\hline 20 & 100 & 17 & 2 & 2 & 2 & 0 & 0 & 0 & 0 & 124 & 5 & 22 & 14.3 & 6.3 & 7.8 \\
\hline 21 & 6400 & 15 & 3 & 5 & 2 & 0 & 2 & 0 & 0 & 179 & 113 & 301 & 14.5 & 5.6 & 5.0 \\
\hline Mean & & 14 & 5 & 3 & 2 & 0 & 0 & 0 & 0 & 221 & 73 & 120 & 12.2 & 5.9 & 5.7 \\
\hline $\begin{array}{l}\text { Standard } \\
\text { deviation }\end{array}$ & & 5 & 2 & 2 & 1 & 0 & 1 & 1 & 1 & 152 & 68 & 112 & 3.4 & 1.1 & 1.3 \\
\hline Median & & 16 & 4 & 3 & 2 & 0 & 0 & 0 & 0 & 224 & 49 & 68 & 12.9 & 5.8 & 5.6 \\
\hline Minimum & & 3 & 2 & 2 & 0 & 0 & 0 & 0 & 0 & 4 & 5 & 8 & 6.0 & 3.5 & 4.0 \\
\hline Maximum & & 20 & 8 & 7 & 3 & 0 & 2 & 2 & 2 & 636 & 226 & 350 & 21.4 & 7.4 & 9.0 \\
\hline$n$ & & 19 & 19 & 17 & 21 & 20 & 21 & 21 & 20 & 21 & 21 & 19 & 21 & 21 & 19 \\
\hline
\end{tabular}

BL, baseline; $\mathrm{n} / \mathrm{a}$, not available.

${ }^{a}$ Data are included up to Week 84, after which Patient 12 refused treatment.

${ }^{b}$ Data are included up to Week 76, after which Patient 14 was returned to the $1.0 \mathrm{mg} / \mathrm{kg}$ dose.

Patient 19. No angiotensin converting enzyme inhibitors or angiotensin receptor blockers were reported as concomitant medications for any patient at baseline or during the 1.0$\mathrm{mg} / \mathrm{kg}$ period; Patients 15, 17, 18, and 19 started to receive angiotensin converting enzyme inhibitors during the 0.3 $\mathrm{mg} / \mathrm{kg}$ period.

\section{IgG antibodies to agalsidase beta}

Of the 21 patients, 18 became seropositive during the first 12 weeks of treatment and developed peak titers ranging from 100 to
25,600 (Table 3). Over time, three patients tolerized (reverted to seronegative status), two maintained low titers $(\leq 800)$, and 8 exhibited $\geq 4$-fold reductions in titers from peak to final measurement; the remaining five demonstrated $<4$-fold reductions in titer. The highest antibody titers occurred in two patients with coding region deletions (c.674_733 and c.717_718, respectively) that predicted truncated forms of the $\alpha \mathrm{GAL}$ protein. The three patients who remained seronegative had either the p.Ile317Thr or the p.Glu341Gly substitution, and the three patients who tolerized had an p.Ile317Thr, p.Glu341Gly, or p.Asn34Ser substitution. IgE an- 


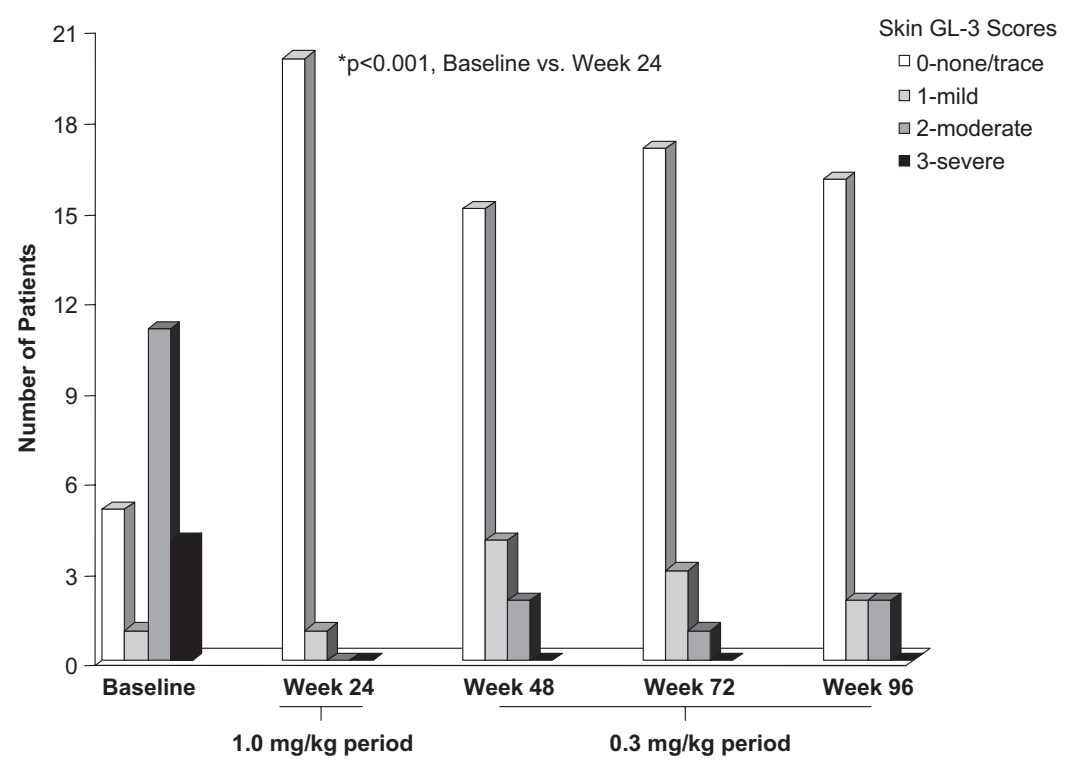

Fig. 1. Scores for GL-3 accumulation in dermal capillary endothelial cells after 6 months of treatment with the standard dose and during 18 months of treatment with a lower dose of agalsidase beta. $P<0.001$ for the percentage of patients with zero scores at Week 24 compared to baseline.

tibodies to $\alpha \mathrm{GAL}$ were not monitored routinely, but they were not detected in two patients who were tested during the study.

\section{Post hoc analyses}

Urine GL-3 levels decreased from a mean (SD) of 221 (152) $\mu \mathrm{g} / \mathrm{mg}$ creatinine at baseline to 37 (35) $\mu \mathrm{g} / \mathrm{mg}$ creatinine at Week 12 , but partially rebounded to 109 (120) $\mu \mathrm{g} / \mathrm{mg}$ creatinine at Week 24 of the $1.0-\mathrm{mg} / \mathrm{kg}$ period. Levels averaged 120 (112) $\mu \mathrm{g} / \mathrm{mg}$ creatinine during the $0.3-\mathrm{mg} / \mathrm{kg}$ period, but varied considerably within and between patients. To explore whether IgG antibodies may have affected clearance of GL-3, patients were stratified into four subgroups (see Fig. 2). Patients who were seronegative at all assessments were in the seronegative subgroup, and patients who were seropositive were ranked by peak titer and divided into three subgroups of approximately equal size to form the lowest-, intermediate-, and highest titer subgroups. As shown in Figure 2, mean levels of urine GL-3 were significantly below baseline during both treatment periods in the seronegative and lowest-titer patients, but not in the highest-titer patients. For intermediate-titer patients, mean urine GL-3 was significantly lower than baseline during the $1.0-\mathrm{mg} / \mathrm{kg}$ period, but not during the $0.3-\mathrm{mg} / \mathrm{kg}$ period. Meaningful subgroup analyses of GL-3 levels in plasma and in kidney and skin cells were precluded by insufficient numbers of patients who had abnormal GL-3 levels both at baseline and during treatment, but it is notable that only patients in the intermediate- or highest-titer subgroups had nonzero scores assigned to the capillary endothelial cells of the kidney interstitium or the skin superficial dermis during the 0.3 -mg period, whereas no seronegative or lowest-titer patient had a recurrence of nonzero scores in these cells.

\section{Safety}

A total of 30 AEs were reported for nine patients during the 6-month, $1.0-\mathrm{mg} / \mathrm{kg}$ period, and 87 AEs for 13 patients during the 18 -month, $0.3-\mathrm{mg} / \mathrm{kg}$ period. The most frequently occurring AEs without regard to causality included diarrhea, chills, and pyrexia. No clinically meaningful differences were discerned in the types of AEs reported during the 1.0 - and $0.3-\mathrm{mg} / \mathrm{kg}$ peri- ods. Most AEs (98 of 117) were assessed as not related to treatment. Of the 19 AEs considered related to treatment, 18 occurred during an infusion and were considered infusionassociated reactions (IARs): 10 IARs were reported for five patients in the $1.0-\mathrm{mg} / \mathrm{kg}$ period and eight IARs were reported for three patients during the first 6 months of the $0.3-\mathrm{mg} / \mathrm{kg}$ period. During both dose periods, all IARs were mild or moderate in intensity, with chills and pyrexia reported most commonly. A total of nine serious adverse events (SAEs) were reported for five patients. None was considered treatment-related and no deaths occurred, but two patients experienced SAEs during the $0.3-\mathrm{mg} / \mathrm{kg}$ period that were assessed as severe in intensity: complete atrioventricular block in Patient 10 and cerebral ischemia, syncope, and dehydration in Patient 8 , who recovered with sequelae of dysarthria and weakness. No clinically meaningful changes were noted over time for clinical laboratory results, vital signs, electrocardiograms, or concomitant medication use during either dose period.

\section{DISCUSSION}

This exploratory study was undertaken in adult male patients with Fabry disease to investigate whether a lower, $0.3-\mathrm{mg} / \mathrm{kg}$ dose of agalsidase beta could maintain the cellular clearance of GL-3 that was initially achieved by treatment with $1.0-\mathrm{mg} / \mathrm{kg}$, the recommended therapeutic dose. The development of renal dysfunction in Fabry disease is associated with chronic deposition of incompletely catabolized substrates in the kidney microvascular endothelium. ${ }^{1,18,19}$ The endothelial cells of the interstitial capillaries were selected for the primary endpoint assessment, as in the pivotal Phase 3 trial of agalsidase beta, ${ }^{4}$ because they are abundant in all biopsy specimens, even those that lack glomeruli, and provide 100 or more vessels for evaluation per sample. For three patients in the present study, no GL-3 deposits were observed in the interstitial capillary endothelium in pre- or post-treatment biopsy samples. Of the remaining 18 patients with mild to severe accumulation at baseline, GL-3 clearance was achieved in all of them after 6 months 


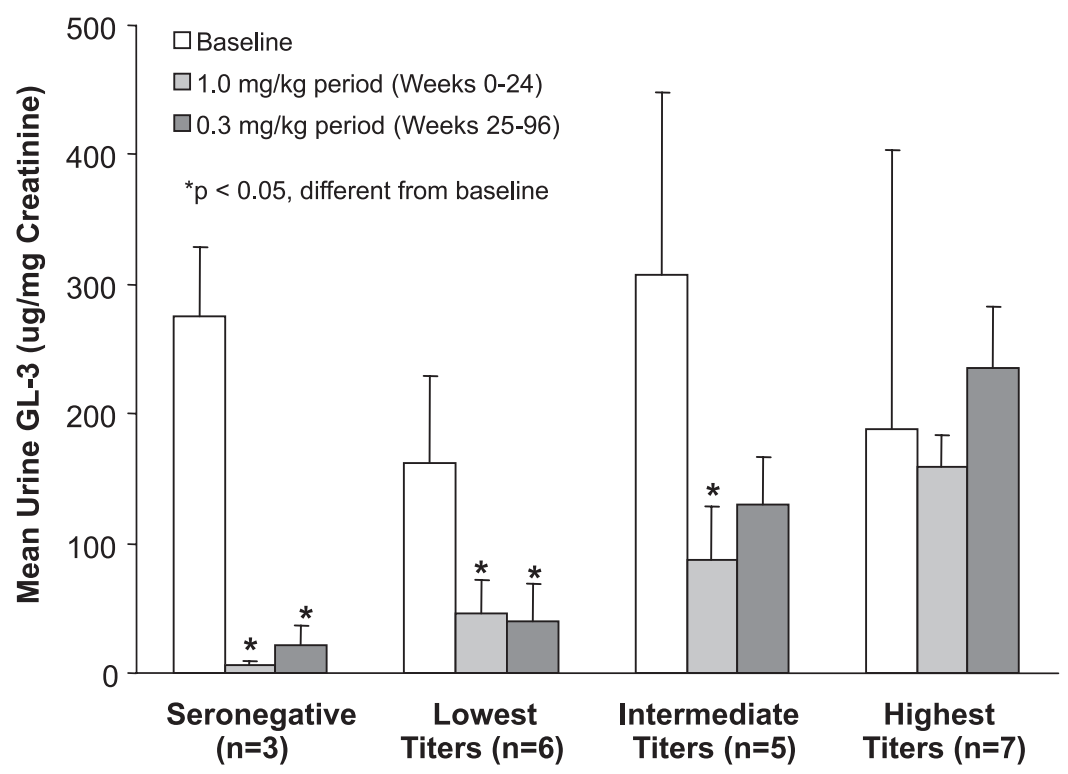

Fig. 2. Urine GL-3 over time as a function of peak titer subgroup. Patients were stratified by peak titer values, as follows: Patients 16, 17, and 19 were seronegative; Patients 2, 10,11,13, 18, and 20 were in the lowest-titer group with peak titers between 100 and 800; Patients 1, 5, 7, 9, and 12 were in the intermediate titer group with peak titers of 3200, and Patients 3, 4, 6, 8, 14, 15, and 21 were in the highest-titer group with peak titers between 6,400 and 25,600. For each patient, data were used from a single baseline assessment, from the average of two assessments during the 1.0-mg/kg period, and from the average of six assessments during the $0.3-\mathrm{mg} / \mathrm{kg}$ period. For each subgroup, the means and standard deviation are presented, and a paired $t$-test was used to compare the baseline mean to the means for the 1.0and the $0.3-\mathrm{mg} / \mathrm{kg}$ periods.

at the $1.0-\mathrm{mg} / \mathrm{kg}$ dose and sustained in 15 of them during 18 months at the $0.3-\mathrm{mg} / \mathrm{kg}$ dose. Mild GL-3 accumulation was observed in two patients and a final assessment was not available for one patient at the end of the $0.3-\mathrm{mg} / \mathrm{kg}$ period. No statistically significant difference was found between the standard- and low-dose periods in the percentage of patients with zero scores, but the study was not powered to do so; hence, the conclusion that the $0.3-\mathrm{mg}$ dose is equivalent to the $1.0 \mathrm{-mg}$ dose is not robustly supported given the small number of evaluable patients and the recurrence of nonzero scores in two patients. However, the results do suggest that, after initial treatment with agalsidase beta at $1.0 \mathrm{mg} / \mathrm{kg} / 2$ weeks, a lower dose of $0.3 \mathrm{mg} / \mathrm{kg}$ may be sufficient to maintain cellular clearance of GL-3 in the renal microvascular endothelium in some patients.

Multiple kidney cell types are affected in Fabry disease, and a total of eight cell types were evaluated in this study, including the endothelia in three populations of microvessels that differ in their location and function within the kidney. Composite kidney GL-3 scores were computed by summing the eight cell scores for a given patient, and they ranged from three in a patient with GL-3 observed only in podocytes to 20 in a patient with moderate or severe GL-3 accumulation in all cell types. Despite the variability within the small cohort, dramatic declines in composite scores were seen after the $1.0-\mathrm{mg} / \mathrm{kg}$ period and were maintained during the $0.3-\mathrm{mg} / \mathrm{kg}$ period in 14 of the 17 patients with available composite scores. Even though the composite score provides a single value to estimate the overall kidney GL-3 burden and to monitor changes with treatment, it has the following limitations: it does not take into account the relative physiological importance of different cell types; it can only be computed if all eight cell types are assessable in a given specimen; and it can mask increases (worsening) in some cell scores when offset by decreases (improvement) in others. When scores were examined for each cell type at the end of the $0.3-\mathrm{mg} / \mathrm{kg}$ dose period, six patients showed an increase in the GL-3 score for one or more renal cell types, most often the distal convoluted tubule/collecting duct cells. Hence, the ability of the $0.3-\mathrm{mg} / \mathrm{kg}$ dose to maintain clearance in some, but not all, patients was observed in more than one type of kidney cell.

Assessments of the superficial dermal capillary endothelial cells of the skin also revealed recurrence of GL-3 accumulation during the low-dose period in some patients. Previous studies have shown that GL-3 clearance from the capillary endothelia of the kidney, heart, and skin occurs in parallel during agalsidase beta therapy, and the less invasive skin biopsy has been used for more frequent evaluations and for follow-up over longer periods of treatment. ${ }^{4-7}$ In the present study, skin biopsies were obtained at baseline, after 6 months of therapy with agalsidase beta at $1.0 \mathrm{mg} / \mathrm{kg} / 2$ weeks, and at up to three time points during 18 months of treatment at $0.3 \mathrm{mg} / \mathrm{kg} / 2$ weeks. During a Phase 3 trial and its extension study involving 58 adult patients with Fabry disease, ,5,6,11,17 skin biopsies were also obtained at baseline and after 6 months at $1.0 \mathrm{mg} / \mathrm{kg} / 2$ weeks, and then at up to six time points during up to 54 months of continued treatment at the $1.0-\mathrm{mg} / \mathrm{kg}$ dose. The proportion of males who had pretreatment scores of zero in the dermal capillary endothelium was higher in the present study (5 of 16) compared to the Phase 3 -extension study ( 2 of 56). However, in the patients with nonzero scores at baseline, the two study cohorts were similar in the extent of GL-3 accumulation ( $\sim 25 \%$ were assessed as severe, $70 \%$ as moderate, and $5 \%$ as mild) and in the proportion who achieved zero scores during the first 6 months at $1.0 \mathrm{mg} / \mathrm{kg} / 2$ weeks (15 of 16 patients in the present study and 53 of 54 patients in the Phase 3 studies). Differences 
between the study cohorts emerged after the first 6 months. First, a nonzero score was observed in $40 \%$ (6 of 15) of patients on at least one assessment during treatment with $0.3 \mathrm{mg} / \mathrm{kg} / 2$ weeks, compared to $21 \%$ (11 of 53) of patients who continued treatment with $1.0 \mathrm{mg} / \mathrm{kg} / 2$ weeks. The proportion of patients with a recurrence of GL-3 accumulation was higher in the present study even though patients were followed for a shorter period of time on the $0.3 \mathrm{mg} / \mathrm{kg}$ dose (18 months) relative to those on the $1.0 \mathrm{mg} / \mathrm{kg}$ dose in the Phase 3 extension study (up to 54 months). Second, recurrence of GL-3 accumulation after initial clearance was noted sooner at the $0.3-\mathrm{mg} / \mathrm{kg}$ dose: in the 6-month interval subsequent to clearance, a nonzero score was assigned to $33 \%$ (5 of 15) of patients treated with $0.3 \mathrm{mg} / \mathrm{kg}$ compared to $2 \%$ ( 1 of 53 ) of patients treated with $1.0 \mathrm{mg} / \mathrm{kg}$. Third, the degree of GL-3 reaccumulation seemed to be more severe with the lower dose. The highest (worst) GL-3 score was mild for $50 \%$ and moderate for $50 \%$ of the six patients with nonzero scores during treatment with $0.3 \mathrm{mg} / \mathrm{kg}$, compared to $91 \%$ (10 of 11 ) with mild and $9 \%$ (1 of 11) with moderate scores during treatment with $1.0 \mathrm{mg} / \mathrm{kg}$. Consistent with other reports showing that clearance of GL-3 is dose-dependent, 5,20 $1.0-\mathrm{mg} / \mathrm{kg}$ of agalsidase beta seems to be more effective than $0.3 \mathrm{mg} / \mathrm{kg}$ in maintaining GL-3 clearance from dermal microvascular endothelium in male patients with Fabry disease over extended periods of time.

A statistically significant difference was not observed for mean plasma GL-3 values between the two treatment periods, but notably an elevated level recurred on at least one occasion during $0.3-\mathrm{mg} / \mathrm{kg}$ treatment in nine patients who had normalized at the end of $1.0-\mathrm{mg} / \mathrm{kg}$ treatment. Mean urine GL-3 was statistically different in the standard- and low-dose periods. Impairment of GL-3 clearance from urine, ${ }^{21-23}$ and from skin cells, ${ }^{17}$ has previously been associated with the formation of circulating IgG antibodies to agalsidase beta during ERT. Therefore, a post hoc analysis was undertaken to explore the possible influence of antibodies in patients who displayed abnormal baseline levels of GL-3 that did not normalize or that recurred during low-dose therapy. Although statistical testing was limited to urine GL-3 due to small numbers of patients with both pre- and post-treatment elevations of GL-3 in plasma, skin cells, or kidney cells, it seemed that patients who remained seronegative or who developed only low $\operatorname{IgG}$ titers tended to consistently maintain reduced or normal GL-3 levels during treatment with the low, $0.3-\mathrm{mg} / \mathrm{kg}$ dose. Similarly, a recent report ${ }^{20}$ showed that, when patients were treated for 12 months with a low dose $(0.2 \mathrm{mg} / \mathrm{kg})$ of agalsidase beta or agalsidase alfa (another form of recombinant $\alpha \mathrm{GAL}$ ), urine GL-3 declined in seronegative patients, but not in seropositive patients. Moreover, in the same study, agalsidase beta at the standard dose of $1.0 \mathrm{mg} / \mathrm{kg}$ resulted in decreased levels of urine GL-3 in both seropositive and seronegative patients. These findings raise the possibility that a lower dose of enzyme may be sufficient to maintain GL-3 clearance in seronegative and low-titer patients, whereas some patients with higher titers of antibodies may require higher doses to effect and maintain GL-3 clearance. It is important to note that the level of GL-3 in urine, plasma, or cells has not yet proven to be a biomarker for predicting long-term clinical outcomes ${ }^{2}$ and that $\operatorname{IgG}$ antibodies to agalsidase beta have not been found to negatively affect clinical outcomes in patients during treatment with $1.0 \mathrm{mg} / \mathrm{kg} / 2$ weeks. ${ }^{17,20,22} \mathrm{In}$ the present study, no negative effect of IgG antibodies or of the lower dose was discerned on renal function in a cohort of adult Fabry males mostly with chronic kidney disease Stage 1 or 2 , but the small sample size together with the short duration of this exploratory study did not permit analyses of clinical outcomes.
In the recently reported study ${ }^{20}$ that directly compared the standard dose $(1.0 \mathrm{mg} / \mathrm{kg})$ of agalsidase beta to a lower dose $(0.2 \mathrm{mg} / \mathrm{kg})$ of either agalsidase beta or alfa, left ventricular mass decreased after 12 months of treatment in patients treated with the higher dose, but not with the lower dose. Although other studies have demonstrated the clinical benefit of agalsidase beta administered at $1.0 \mathrm{mg} / \mathrm{kg} / 2$ weeks, ${ }^{6,9,10}$ the long-term clinical ramifications of transitioning to $0.3 \mathrm{mg} / \mathrm{kg}$ have not been evaluated and would require further evaluation before implementation of the lower dose in clinical practice.

No new safety concerns were identified during administration of agalsidase beta at the lower $0.3-\mathrm{mg} / \mathrm{kg}$ dose. All AEs involved symptoms commonly associated with Fabry disease or previously reported to occur during infusions. ${ }^{5,9}$ Most treatment-related AEs were IARs, with five patients (24\%) reporting 10 IARs during the initial standard-dose period and three patients $(14 \%)$ reporting eight IARs during the first 6 months of the subsequent low-dose period. Notably, no IARs were reported during the last 12 months of the low-dose period. Because this was an open-label, single-arm study, formal comparison of IAR frequency between the sequential dose periods was not possible. However, previous studies have demonstrated that the frequency of IARs usually decreases over time in conjunction with declining titers of antibodies, optimization of infusion conditions and administration of prophylactic medications. ${ }^{6,9,11}$

In summary, this prospective, open-label study of agalsidase beta was undertaken to explore whether transitioning from a standard dose of $1 \mathrm{mg} / \mathrm{kg}$ to a lower dose of $0.3 \mathrm{mg} / \mathrm{kg}$ affected the cellular clearance of GL-3 initially achieved at the standard dose. The results suggest that the lower dose may maintain GL-3 clearance in some patients with Fabry disease, but other patients seem to require a dose higher than $0.3 \mathrm{mg} / \mathrm{kg}$ to prevent recurrence of GL-3 accumulation in cells. The long-term clinical effects of transitioning to the lower dose were not evaluated. The main limitations of the study were that the patient population was small and heterogeneous and that cells were evaluated from only two organs in this multisystemic disease, precluding broad, definitive conclusions. Nevertheless, the results clearly show variability in responsiveness to the lower dose of agalsidase beta and suggest that dosing strategies that deviate from the recommended therapeutic regimen of $1.0 \mathrm{mg} /$ $\mathrm{kg} / 2$ weeks should be systematically monitored. Conducting adequately powered, parallel-control studies to investigate doseresponse relationships or to evaluate alternative dosing regimens remains a challenge due to the rarity and heterogeneity of Fabry disease and the lack of a biomarker to predict long-term clinical outcomes. Recently, observational data from the disease registry of another rare lysosomal storage disorder, the International Collaborative Gaucher Group Gaucher Registry, have been evaluated using advanced statistical methods to define ERT dose-response relationships in a large patient cohort over a long period of follow-up. ${ }^{24}$ The Fabry Registry ${ }^{25}$ may ultimately provide a similar mechanism for deriving evidencebased conclusions about optimal treatment regimens among subpopulations of patients with Fabry disease, and the voluntary participation of treating physicians and their patients in the registry program is encouraged.

\section{ACKNOWLEDGMENTS}

This study was funded by Genzyme Corporation. Histological assessments of kidney tissue were conducted by Robert B. Colvin, MD (Massachusetts General Hospital, Boston, MA, USA), Steven Dikman, MD (Mount Sinai School of Medicine, New York, NY, USA), and Helmut Rennke, MD (Brigham and 
Women's Hospital, Boston, MA, USA). Histological assessments of skin tissue were conducted by H. Randolph Byers, $\mathrm{MD}, \mathrm{PhD}$ (Boston University Medical Center, Boston, MA, USA), Scott Granter, MD (Brigham \& Women's Hospital, Boston, MA, USA), and Robert Phelps, MD (Mount Sinai School of Medicine, New York, NY, USA). The authors acknowledge the contributions to this work of Timothy Foley; Sunita Goyal, MD; Andrea M. Norfleet, PhD; Fanny O'Brien, $\mathrm{PhD}$; Crystal Sung, PhD; Karen Welch; and Arnold Willemsen (Genzyme Corporation).

\section{REFERENCES}

1. Desnick RJ, Ioannou YA, Eng CM, Alpha-galactosidase A deficiency: Fabry disease. In: Scriver CR, Beaudet A, Sly W, Valle D, editors. Metabolic and molecular bases of inherited disease. New York: McGraw Hill, 2001:37333774.

2. Aerts JM, Groener JE, Kuiper S, et al. Elevated globotriaosylsphingosine is a hallmark of Fabry disease. Proc Natl Acad Sci U S A 2008;105:2812-2817.

3. Barbey F, Brakch N, Linhart A, et al. Cardiac and vascular hypertrophy in Fabry disease: evidence for a new mechanism independent of blood pressure and glycosphingolipid deposition. Arterioscler Thromb Vasc Biol 2006;26: 839-844.

4. Eng CM, Guffon N, Wilcox WR, et al. Safety and efficacy of recombinant human alpha-galactosidase A-replacement therapy in Fabry's disease. $N$ Engl J Med 2001;345:9-16.

5. Eng CM, Banikazemi M, Gordon RE, et al. A phase $1 / 2$ clinical trial of enzyme replacement in Fabry disease: pharmacokinetic, substrate clearance, and safety studies. Am J Hum Genet 2001;68:711-722.

6. Germain DP, Waldek S, Banikazemi M, et al. Sustained, long-term renal stabilization after 54 months of agalsidase beta therapy in patients with Fabry disease. J Am Soc Nephrol 2007;18:1547-1557.

7. Wraith JE, Tylki-Szymanska A, Guffon N, et al. Safety and efficacy of enzyme replacement therapy with agalsidase beta: an international, openlabel study in pediatric patients with Fabry disease. J Pediatr 2008;152:563570 .

8. Breunig F, Weidemann F, Strotmann J, Knoll A, Wanner C. Clinical benefit of enzyme replacement therapy in Fabry disease. Kidney Int 2006;69:12161221 .

9. Banikazemi M, Bultas J, Waldek S, et al. Agalsidase beta therapy for advanced Fabry disease: a randomized trial. Ann Intern Med 2007;146:7786.

10. Weidemann F, Breunig F, Beer M, et al. Improvement of cardiac function during enzyme replacement therapy in patients with Fabry disease: a prospective strain rate imaging study. Circulation 2003;108:1299-1301.

11. Wilcox WR, Banikazemi M, Guffon N, et al. Long-term safety and efficacy of enzyme replacement therapy for Fabry disease. Am J Hum Genet 2004; 75:65-74.

12. Thurberg BL, Byers HR, Granter SR, et al. Monitoring the 3-year efficacy of enzyme replacement therapy in Fabry disease by repeated skin biopsies. $J$ Invest Dermatol 2004;122:900-908.

13. Thurberg BL, Rennke H, Colvin RB, et al. Globotriaosylceramide accumulation in the Fabry kidney is cleared from multiple cell types after enzyme replacement therapy. Kidney Int 2002;62:1933-1946.

14. Roddy TP, Nelson BC, Sung CC, et al. Liquid chromatography-tandem mass spectrometry quantification of globotriaosylceramide in plasma for longterm monitoring of Fabry patients treated with enzyme replacement therapy. Clin Chem 2005;51:237-240.

15. Kitagawa T, Ishige N, Suzuki K, et al. Non-invasive screening method for Fabry disease by measuring globotriaosylceramide in whole urine samples using tandem mass spectrometry. Mol Genet Metab 2005;85:196-202.

16. Levey AS, Bosch JP, Lewis JB, Greene T, Rogers N, Roth D. A more accurate method to estimate glomerular filtration rate from serum creatinine: a new prediction equation. Modification of diet in renal disease study group. Ann Intern Med 1999;130:461-470.

17. Benichou B, Goyal S, Sung C, Norfleet AM, O'Brien F. A retrospective analysis of the potential impact of IgG antibodies to agalsidase $\beta$ on efficacy during enzyme replacement therapy for Fabry disease. Mol Genet Metab 2009;96:4-12.

18. DeGraba T, Azhar S, Dignat-George F, et al. Profile of endothelial and leukocyte activation in Fabry patients. Ann Neurol 2000;47:229-233.

19. Sakuraba H, Igarashi T, Shibata T, Suzuki Y. Effect of vitamin E and ticlopidine on platelet aggregation in Fabry's disease. Clin Genet 1987;31: $349-354$.

20. Vedder AC, Breunig F, Donker-Koopman WE, et al. Treatment of Fabry disease with different dosing regimens of agalsidase: effects on antibody formation and GL-3. Mol Genet Metab 2008;94:319-325.

21. Linthorst GE, Hollak CE, Donker-Koopman WE, Strijland A, Aerts JM. Enzyme therapy for Fabry disease: neutralizing antibodies toward agalsidase alpha and beta. Kidney Int 2004;66:1589-1595.

22. Ohashi T, Sakuma M, Kitagawa T, Suzuki K, Ishige N, Eto Y. Influence of antibody formation on reduction of globotriaosylceramide (GL-3) in urine from Fabry patients during agalsidase beta therapy. Mol Genet Metab 2007;92:271-273.

23. Vedder AC, Linthorst GE, Houge G, et al. Treatment of Fabry disease: outcome of a comparative trial with agalsidase alfa or beta at a dose of 0.2 $\mathrm{mg} / \mathrm{kg}$. PLOS ONE 2007;2:e598.

24. Grabowski GA, Kacena K, Cole JA, et al. Dose-response relationships for enzyme replacement therapy with imiglucerase/alglucerase in patients with Gaucher disease type 1. Genet Med 2009;11:92-100.

25. Eng CM, Wilcox WR, Waldek S, et al. Fabry Disease Registry: Baseline medical characteristics in a cohort of 1213 males and females. $J$ Inherit Metab Dis 2007;30:184-192. 